russona

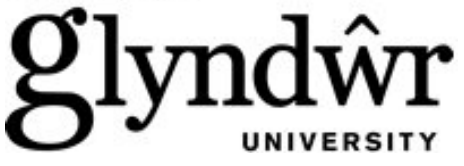

Glyndŵr University

Glyndŵr University Research Online

Advanced Materials Research Laboratory

Materials Science

$10-1-2006$

\title{
Medical Applications of Solid State Ionics
}

Roger Linford

Glyndwr University, r.linford@glyndwr.ac.uk

Walkiria Schlindwein

Follow this and additional works at: http:/ / epubs.glyndwr.ac.uk/amrl

Part of the Biomedical devices and instrumentation Commons

\section{Recommended Citation}

Linford, R., \& Schlindwein, W. (2006) Medical applications of solid state ionics. Proceedings of the 15th International Conference on Solid State Ionics: Vol 177 Solid State Ionics (pp. 1559-1565)

This Article is brought to you for free and open access by the Materials Science at Glyndwir University Research Online. It has been accepted for inclusion in Advanced Materials Research Laboratory by an authorized administrator of Glyndŵr University Research Online. For more information, please contact d.jepson@glyndwr.ac.uk. 


\title{
Medical Applications of Solid State Ionics
}

\begin{abstract}
Solid State Ionic materials and devices are being used in medicine in many ways. A brief initial introduction to the materials, the devices and the pertinent electrophysiological and clinical aspects is presented. To exemplify the breadth of SSI material and device applications, an overview is given of three main areas: Biomedical applications of solid state power sources; Biofuel cells; and Iontophoretic and related devices used for controlled transdermal drug delivery and monitoring of physiological parameters
\end{abstract}

\section{Keywords}

drug delivery, iontophoretic devices, bioelectrochemistry, biological fuel cells, biomedical devices

\section{Disciplines}

Biomedical devices and instrumentation

\section{Comments}

The origional version was published by Elseiver and can be found at www.sciencedirect.com Copyright (C) 2006 Elsevier B.V. 


\title{
Medical Applications of Solid State Ionics
}

$\underline{\text { Roger Linford }}^{1}$ and Walkiria Schlindwein ${ }^{2}$

${ }^{1}$ Research Office and ${ }^{2}$ School of Pharmacy,

De Montfort University, The Gateway, Leicester LE1 9BH, England

Email: rgl@dmu.ac.uk

\begin{abstract}
Solid State Ionic materials and devices are being used in medicine in many ways. A brief initial introduction to the materials, the devices and the pertinent electrophysiological and clinical aspects is presented. To exemplify the breadth of SSI material and device applications, an overview is given of three main areas: Biomedical applications of solid state power sources; Biofuel cells; and Iontophoretic and related devices used for controlled transdermal drug delivery and monitoring of physiological parameters
\end{abstract}

Keywords: drug delivery, iontophoretic devices; bioelectrochemistry; biological fuel cells; biomedical devices

\section{Introduction}

The importance of electrochemistry in facilitating and controlling the passage of ions in living tissues is universally acknowledged. Without redox reactions taking place within the body, life as we know it would cease. Electrochemistry also causes the production and storage of electrical energy from chemical reactions in power sources such as batteries and fuel cells. 
Advances in solid state ionics applications have required painstaking and careful materials development over the past forty years. Medical applications of power sources and of their component materials impose their own strict requirements and constraints on device and material selection and often involve highly miniaturised systems. The interdependence of the requirements of the solid state ionics and medical fields is shown schematically in figure 1. In this paper, three particular areas at different stages of maturity - biomedical power sources, biofuel cells and iontophoretic devices - have been chosen to illustrate present and future applications of solid state ionic devices and their component materials in medicine.

Solid State batteries are well suited to medical applications as they are inherently compact, robust, well encapsulated and spill-proof and can be implanted safely within the body to ensure long term stability and availability of power. Applications up to the early part of this decade have been reviewed elsewhere [1]; more recent advances are described in section 2 .

As diagnostic medicine advances, there is an increasing need for sensors that can transmit signals from within the part of the body that is malfunctioning. Such sensors require a power source to be connected to them in order to function. Connection by wire to the sensor is usually impossible without impeding the normal functioning of the patient's body. Wireless supply of sufficient power cannot be achieved at present without interference with normal bodily functions. Consequently ultra-miniaturised biofuel cells are now being studied which can actually reside within the tissue or organ that is affected. Such fuel cells need to be supplied by reactants such as oxygen and glucose, which are physiologically available form the immediate environment. The development of biofuel cells builds on earlier work on biosensors and other devices using biocatalysis and substantial progress is being made in this fast moving field [2-4]. For clarity, biofuel cells are described as microbial if living cells are involved and as enzymatic if they are not. 
Applications of microbial cells are reviewed elsewhere [5]. Section 3 focuses on medical applications of enzymatic fuel cells.

Some electrolyte materials used in polymer solid state batteries can be modified to provide the drug reservoir in a particular type of medical drug delivery system known as an iontophoretic device. This is externally mounted on the skin and the drug, which has to be ionic for this application, is driven into the bloodstream transdermally by the application of a voltage from an external power source. Developments of a range of iontophoretic and related devices have been discussed elsewhere $[6,7]$ and recent advances are outlined in section 4 .

\section{Medical Applications of Solid State Power Sources}

External or implanted power sources such as batteries and fuel cells are used in a variety of ways in medicine [1], including motorised wheelchairs; surgical tools; cardiac pacemakers and defibrillators; dynamic prostheses; sensors and monitors for physiological parameters; neurostimulators; devices for pain relief; and iontophoretic, electroporative and related devices for drug administration. It is helpful to separate applications into two categories by location of the power source. External devices are those which are connected to the patient by wire. In some cases the power source can be attached or transdermal, i.e. external to the body but located on the skin. By contrast, implanted devices are located within the body.

In some cases such as that of the heart pacemaker battery, the implanted power source is situated remotely, i.e. at a different location from that of the device which it powers [8]. In others, such as planned autonomous sensor-transmitters powered by ultraminiature fuel cells, the power source will be attached to the device [4]. 


\subsection{External Applications}

Some applications such as motorized wheelchairs and some battery powered surgical implements have power requirements which are too large to be met by solid state devices [1]. There are other cases, e.g. left ventricular assist devices used for patients awaiting heart transplants, where a substantial power requirement is met by a combination of external and implanted batteries [8].

Prototype devices are being developed to take over the functions of the semicircular canals in the ear, which act as physiological rotation sensors to preserve balance. They use piezoelectric vibrating gyroscopes to measure the angular velocity of the head. $\mathrm{Pt}$ electrodes are powered by Li batteries which, together with the sensors and computerised frequency converters are mounted externally [9]. A variety of sensors and monitors such as glucose sensors for diabetics and "halter" monitors storing electrocardiogram signals are powered by external batteries at present [8]. In the future, many of these may be developed to utilise miniaturised and implanted fuel cells [4] to provide "real time, true location" signal detection.

Electric shocks from torpedo fish were used in ancient Greece to treat gout and the first example of the use of an electric current to increase penetration of ionic drugs into and through surface tissue was in 1747 [7]. The term iontophoresis was introduced for this process in the $19^{\text {th }}$ century [10]. A variety of power sources has been used for iontophoresis $[6,7,11,12]$ and for related processes such as electroporation [13]. External power sources have also been used to control drug delivery from implantable reservoirs [1] in order to improve patient compliance with a given therapy, the relative ease of self-dosing eliminating the need for multiple intravenous injections [14].

Power sources for transdermal devices for iontophoresis and related processes can themselves be located on the skin and integrated with the drug reservoir and electrodes [6, $7,12]$. 


\subsection{IMPLANTED POWER SOURCES}

Monitoring the responses of individuals to drugs and other stimuli is very important as drugs are presently administered at frequencies and doses based on averages which have been optimised for large, often heterogeneous, populations. Individual behaviour differs, either permanently or temporarily, from the average and it is therefore desirable to have individualised, integrated medical systems comprising implanted sensors, batteries, amplifier, processor and actuator for such applications as heart pacemakers and defibrillators [15].

Most implanted power sources are located remotely from the device they power. Neurostimulators for pain relief, tremour reduction in Parkinson's disease [1], incontinence [16] and epilepsy [17] also have a power demand within the range of implanted batteries. Recent studies have investigated the possible interaction between such devices and the high magnetic fields used in MRI scanning [18].

The largest application of remote, implanted batteries, however, is the heart pacemaker in which the Li battery is located below the skin between the shoulder and the neck and is connected to electrodes in the heart muscle [19]. The heart pacemaker was initially developed in 1959 [20] and the first that was powered with a Li battery was implanted in 1972 [21]. It is designed to assist in bradycardia, an illness where the heart beats too slowly. A similar device, the implantable cardiac defibrillator, addresses tachycardia, a medical condition where the heart beats too quickly [22] and which, if untreated, can degenerate into ventricular fibrillation and death.

An example of a power source directly attached to an implanted device, which is currently undergoing clinical trials is a fully implanted hearing aid using pacemaker-type batteries integrated with the rest of the device and located just behind the ear [23]. Perhaps 
the most exciting future development, hopefully to be realised soon, is implantable sensortransmitter systems, smaller than $1 \mathrm{~mm}^{3}$ powered by integral glucose - oxygen biofuel cells [4].

\subsection{TYPES OF SOLID STATE POWER SOURCES USED IN MEDICINE}

Li / Silver vanadium oxide (SVO) batteries are used, in conjunction with stacked plate aluminium electrolytic capacitors, to power implantable cardioverter-defibrillators. The electrode balance needs to be carefully optimised [24]. Alternative systems include Li / $\mathrm{CF}_{\mathrm{x}}$ and $\mathrm{Li} / \mathrm{MnO}_{2}(\mathrm{MDX})$ [25]. The $\mathrm{Li} / \mathrm{I}_{2}-\mathrm{PVP}$ primary battery is the system of choice for low rate applications such as pacemakers $[26,27]$. Implantable Li Ion batteries have been used in test systems for undulation pump total artificial hearts [28]. Potential nanobiotechnological devices including molecular motors and artificial organs and their power sources have recently been reviewed [29]. Optimisation studies are being carried out to facilitate future implantable fuel cells [30] and systems involving chitosan (extracted from shellfish shells, one of the world's largest sources of discarded materials) are also being proposed for implanted batteries [31]. Dangers accompanying the use of batteries in medicine have recently been reviewed elsewhere [1].

\section{Enzymatic Biofuel Cells}

Batteries and fuel cells are both electrochemical devices in which electrons move through an external circuit where they can do electrochemical work and the charge compensating ions move from one electrode to another through an electrolyte membrane. In the former, the electrode material cannot be replenished (although in rechargeable or secondary batteries, the ions can be sent back to the electrodes from which they came) whereas in the latter, the electrode fuel, usually gaseous or liquid, can be continuously 
supplied and is catalytically converted to active electrode material, usually by a precious metal catalyst.

A biological fuel cell or biofuel cell is a hybrid of fuel cell technology and biotechnology and the catalysts are enzymatic, either contained in microorganisms or as isolated proteins. There was a particular interest in the USA in the 1960s in developing biofuel cells as energy-saving, waste disposal systems for extended space flights [32]. Biofuel cells cannot approach the performance of conventional systems. Platinum based hydrogen - air and methanol fuel cells can achieve $1 \mathrm{~A} / \mathrm{cm}^{2}$ and $0.65 \mathrm{~V}$ and $0.5 \mathrm{~A} / \mathrm{cm}^{2}$ and $0.5 \mathrm{~V}$ respectively whereas the best methanol-air biofuel cells produce less than $10 \mathrm{~m} \mathrm{~A} / \mathrm{cm}^{2}$ [33].

The focus in this paper is on biofuel cells for medical use (often in miniaturized form), powered by physiologically available reactants and used for diagnostic and related applications. Biofuel cells are similar to biosensors and other devices which use enzymatic biocatalysis although biocatalysed sensors are often inexpensive enough to be disposable, so stability for sensors is not a major issue. Bioelectrocatalysts form molecular transducers which convert chemical into electrical signals [2].

Biofuel cells are described as microbial if living cells are involved and as enzymatic if they are not; see figure 3. A further distinction is between direct and indirect biofuel cells. In the former, fuel is oxidised at the surface of the electrode in an enzymatically catalysed reaction whereas in the latter, the fuel reacts in solution or in a separate compartment and a redox active mediator shuttles electrons between the reaction site and the electrode. Often, enzymes are used in direct fuel cells and microorganisms in indirect configurations [32].

Maximising $\mathrm{V}_{\text {cell }}$ and $\mathrm{I}_{\text {cell }}$ so that power and energy output are as large as possible represent key challenges to biofuel cell development. For a direct fuel cell, $\mathrm{V}_{\text {cell }}$ is the 
difference between the potentials of the fuels, corrected for overpotentials (which are nontrivial and reflect the effects of slow kinetics of heterogeneous electron transfer, ohmic resistances and concentration gradients). For an indirect cell, $\mathrm{V}_{\text {cell }}$ is the difference between the mediator potentials, again corrected for overpotentials [5]. $\mathrm{I}_{\text {cell }}$ is influenced by such factors as electrode size, rate of electrode processes and rate of ion transport across the electrolyte membrane. Power lost to irreversible processes usually appears as heat, the management of which is vital in biofuel cells as enzymes are very temperature sensitive [32].

The most common cathodic fuel for biofuel cells is $\mathrm{O}_{2}$, being readily available with a harmless reaction product (water). It is thermodynamically a good oxidant although kinetically it is poor. ABTS (2,2'-azinobis(3-ethylbenzothiazoline-6-sulphonate) has been used as a cathodic mediator to facilitate diffusion processes [2].

For conventional fuel cells, typical anodic fuels are $\mathrm{H}_{2}$, methane, natural gas, gasoline, diesel fuel or methanol but for biofuel cells reactions involving fuels such as glucose, which are present in the bloodstream, are of particular interest. The common cofactor or anode mediator of choice is nicotinamide adenine dinucleotide $\left(\mathrm{NAD}^{+}\right)$which is reduced by the fuel to NADH and subsequently reoxidised to continue the enzymatic reaction. Over $60 \%$ of the oxidoreductases listed in Enzyme Nomenclature have $\mathrm{NAD}^{+}$or its phosphorylated equivalent $\mathrm{NADP}^{+}$as reactant or product [2]. The standard electrode potential is $-0.32 \mathrm{~V}$ at $\mathrm{pH} 7.0$ with respect to the normal hydrogen electrode $(-0.62 \mathrm{~V}$ vs. SCE at $\mathrm{pH} 7.5)$ but in practice, because activities are not unity, there is a $1 \mathrm{~V}$ overpotential which requires to be minimised if practical biofuel cells are to be achieved.

It can be desirable to contain the enzymes and electron transfer mediators within a small volume to maximise concentration and activity. Membranes cause an unacceptable restriction in diffusional flux and so immobilisation of the active species on a surface, or 
within a tethered polymer brush or network is preferred [2]. Similar issues are encountered in the design of polymer electrolyte materials for flexible battery applications [6].

Enzymes are not only efficient catalysts; they are also very selective. An upper rate limit for enzyme catalysis is around 100 Coulombs per minute from $1 \mathrm{mg}$ of enzyme, i.e. about 1.6A. In practice, however, allowing for practical specific activities, $1 \mathrm{~mA}$ is more realistic [32].

The issues involved in using entire microorganisms in fuel cells have been well reviewed elsewhere [5]. In these microbial fuel cells bacteria such as clostridium butyricum can lead to the production of hydrogen from the fermentation of glucose by a more complicated pathway than is needed for enzymatic fuel cells. In bacteria, glucose is converted to pyruvate and NADH by the Embden-Meyerhof pathway. The pyruvate is then oxidised with ferredoxin ${ }_{\mathrm{ox}}$ oxidoreductase to produce acetyl - $\mathrm{CoA}$ together with $\mathrm{CO}_{2}$ and ferredoxin $n_{\text {red }}$. At the same time, the NADH also reacts with ferredoxin ${ }_{\text {ox }}$ to produce $\mathrm{NAD}^{+}$ and ferredoxin ${ }_{\text {red }}$. The ferredoxin $n_{\text {red }}$ produced by both routes reacts with protons in the presence of hydrogenase to form $\mathrm{H}_{2}$. Ideally $4 \mathrm{~mol}$ of $\mathrm{H}_{2}$ would be produced from $1 \mathrm{~mol}$ of glucose but in practice the yield is only a quarter of this[5].

In enzymatic fuel cells, the demanding operating conditions required to ensure the continuous fermentation of whole living cells are replaced by different, but no less stringent, requirements to ensure the stabilisation and efficient utilisation of sensitive and expensive enzymes. Just as batteries can be used in medicine either as implanted or external devices, enzymatic fuel cells can be developed as external power sources or as miniaturised, implantable devices. For external applications for potential medium power applications, a mediated approach has to be used because redox enzymes cannot directly transfer electrons to the electrodes; their redox centres are insulated by the protein matrices that surround them. A variety of possible approaches have been developed by Willner and co-workers [5]. 
The most promising area for medical applications of biofuel cells is as implantable power sources for macro-scale (e.g. heart pacemaker) or micro-scale (e.g. in-situ, diagnostic, integrated, miniaturised, self-powered sensor) applications.

\subsection{MACRO DEVICE APPLICATIONS}

Natural biocatalysts are physiological species which have adapted to optimise their functioning in complex physiological environments at physiological temperature $\left(\sim 37{ }^{0} \mathrm{C}\right)$ and near neutral $\mathrm{pH}(\sim 7)$. They utilise naturally occurring fuels and oxidants and produce reaction products that the host can tolerate. All these features are promising for potential implantable applications as biocatalytic coated electrodes need not be sealed off from physiological fluids. This is just as well because the price of achieving stability by using protective barrier membranes would be to reduce reactant mass transfer. Typical reactants are already present in rather low concentrations (glucose, $5 \mathrm{mMol} / \mathrm{L}$; oxygen $0.1 \mathrm{mMol} / \mathrm{L}$; lactate $1 \mathrm{mMol} / \mathrm{L}$ ) and maximum current density is therefore limited by the ability of such reactants to diffuse into the bioelectrodes. In the case of electrodes situated in blood vessel walls, transport can be enhanced by blood flow (typically 1 to $10 \mathrm{~cm} / \mathrm{s}$ ). The flux of glucose has been calculated to be only about $1 \mathrm{~mA} / \mathrm{cm}^{2}$ [2] and rates would be even lower in tissue.

Heart pacemakers and a variety of other implanted devices were described in section 2.2. At present the lifetime of a $1 \mathrm{Wh} / \mathrm{mL}$ battery with a typical operating regime of $1 \mu \mathrm{W}$ exceeds 10 years which suffices for pacemaker applications. The best biofuel cell operating today can just achieve one-hundredth of this energy density, giving a lifetime measured in days. Potentially, however, if glucose from the body is used as fuel and oxygen dissolved in body fluids is the oxidant, the implantable biofuel cell could achieve high power density and infinite energy density [2]. 
Damage is caused by the implantation process, especially into blood vessels where clotting is a hazard. Here the surgical procedures are worthwhile only if the cell itself is stable and benign enough to survive more than a year, whereas in tissues shorter lifetimes may still confer benefit. Another risk issue for tissues is the toxicity of the implanted cell components. Many of the relevant enzymes have received GRAS (generally recognised as safe) recognition from the US Food and Drug Administration [34]. Mediators sometimes involve osmium compounds, certain of which are considered as toxic although others have been used for treatment of arthritis [35] and haemophilia [36]. It is suspected that, whereas concentrations involved in manufacture may be hazardous, toxicity at in vivo concentrations may be low [37].

The range of difficulties outlined above means that, even at the present day, the majority of enzyme fuel cells actually involve only one bioelectrode, coupled with a noble metal counter electrode [2]. True biofuel cells involving two enzyme electrodes are still either limited to levels of performance below those which would be useful (e.g. $5 \mu \mathrm{W} / \mathrm{cm}^{2}$ ) for implantable applications, or which are microbial rather than enzymatic [2]. A key problem is to achieve two electrodes both working at the physiological $\mathrm{pH}$ value of 7 . This has been achieved in a methyl viologen mediated bacterial cell in which both electrodes had carbon felt sheets immersed in $\mathrm{pH} 7$ phosphate buffer with freely diffusing catalysts and mediators, the two compartments being separated by an anion exchange membrane. The voltage was adequate at $1.17 \mathrm{~V}$ and the current density was $0.45 \mathrm{~mA} / \mathrm{cm}^{2}$ but the lifetime was unacceptably low at 2 hours [38]; the same team are also working on a compartmentless glucose - oxygen cell [39].

\subsection{MicrosCale DEVICES}

Heller [4] has recently reviewed the work of his team in developing miniature, low cost glucose - oxygen fuel cells to power autonomous sensor-transmitters designed for 
implantation in the tissue under study. Their goal is to produce fuel cells smaller than 1 $\mathrm{mm}^{3}$, lighter than $100 \mu \mathrm{g}$ and costing less than $1 \$$ to power autonomous sensor transmitter packages broadcasting several types of information. Local tissue temperature enables inflammation to be monitored. Local pressure in particular blood vessels or other fluid channels indicates possible fluid blockage which, together with the success of any steps taken for its release can be monitored. A further parameter that can be monitored is any deviation from the normal concentration of a chosen chemical whose presence can be used to monitor the progress of a disease.

The sensor is likely continuously to consume only about $1 \mu \mathrm{W}$. The remaining few $\mu \mathrm{W}$ produced by the miniature fuel cell are needed to charge a small ultracapacitor, capable of storing about $1 \mu \mathrm{J}$ which can produce $1 \mathrm{GHz}$ bursts of $10 \mathrm{~mW}$, for $1 \mathrm{~ms}$ every $10 \mathrm{~s}$ to power the transmitter [4]

A number of prototype fuel cells have been built which are more than 100 times smaller than the smallest present day battery or fuel cell. This size reduction has been achieved by eliminating seven of the nine components needed in conventional fuel cells. The redundant items are: the plumbing to anode and cathode compartments as the cell is surrounded by its fuel dissolved within the ambient body fluids; an external case and case seal, designed to encapsulate the cell components and prevent leakage into the environment; and a membrane and seal providing a sealed matrix for the ion conducting electrolyte.

A conventional fuel cell using a platinum group metal as catalyst has to incorporate a membrane because the catalyst is capable of promoting not only the desired oxidation of the fuel but also the highly undesirable reduction of $\mathrm{O}_{2}$ and a compartment-separating membrane is needed to prevent this. Incidentally, many early glucose - electrooxidising cells also required a membrane because the platinum metal catalysts at their $\mathrm{O}_{2}$ electrodes were fouled by the glucose electrooxidation products. The selectivity of enzyme based catalysts means that undesirable side reactions are not promoted and compartment isolation 
becomes unnecessary [4]. The classic development that led to biofuel cells without membranes was when Willner and co-workers used immobilised bioelectrocatalysts, their enzymes being "wired" to electrodes through electronically conducting hydrogels, to catalyse either glucose oxidation at the anode or $\mathrm{O}_{2}$ reduction at the cathode but not vice versa [40].

An early design involved enzymatic electrodes immobilised within, and mediated by, osmium-based redox hydrogels deposited on $7 \mu \mathrm{m}$ diameter carbon fibres. At present, the cell operates at $\mathrm{pH} 5$ in a citrate buffer saturated with air and containing $15 \mathrm{mMol} / \mathrm{L}$ of glucose and produces $340 \mu \mathrm{A} / \mathrm{cm}^{2}$ and $0.4 \mathrm{~V}$ at $37{ }^{\circ} \mathrm{C}$. Current density decreases by $8 \%$ a day because of limitations in anode performance [2]. The $\mathrm{pH}$ is too far from the physiological level, the redox potential of the anode mediator is too high and the deposited hydrogel film is too thick to permit rapid electron transport. A variant on this design uses an anode mediator with a lower redox potential and a cathode catalyst that functions at $\mathrm{pH} 7$ [41]. The voltage is $0.52 \mathrm{~V}$ and the current density is $340 \mu \mathrm{A} / \mathrm{cm}^{2}$, thus more than doubling the power density achieved. The stability, however, is only marginally better at $6 \%$ current density loss per day. Recent developments are summarised by Heller [4]. Barton and colleagues have discussed [2] the key issues that need to be addressed for implanted biofuel cells to be widely adopted - biocompatibility; better activity and stability (achieved by engineering both the protein molecule and its environment, perhaps by biomimetics [42]); increased current density; improved mediators and / or better immobilisation using controlled nanoporous substrates; extended device lifetimes; greater power ( $\mathrm{mW}$ to $\mathrm{W}$ scale in blood vessels and $\mu \mathrm{W}$ in tissue); and better integration with electrical devices, including multi power source stacks. Solving these problems requires the same type of multidisciplinary approach (from chemists, chemical engineers, materials scientists and, of course, biologists) as was needed to launch the field of solid state ionics. 


\section{Iontophoretic and Related Devices}

There are many routes, each with its own advantages and limitations, that can be chosen to convey a drug from outside the patient to the physiological site of action within the body [6]. For example, many drugs can be taken by mouth (perhaps encapsulated in an appropriate excipient) but the oral route is unsuitable for strong tasting substances. More importantly, some drugs cannot survive in the required active form when they enter the body through the relatively destructive digestive tract, and others have adverse effects on the digestive processes. There is also a cycling effect associated with regular oral delivery, shown in fig 2.

In such cases, one of a number of alternative pathways needs to be chosen [7]. These include insertion of a suppository or a catheter into an orifice other than the mouth; injection from a syringe that penetrates through the skin into a muscle or a vein; inhalation, either nasally or orally, of a drug carried either in wet droplets or as dry powder in a carrier gas, into the lung (which has a very large internal surface area); topically, i.e. by external application of ointments containing volatile active drug which diffuses into the eye, tooth, nail or skin to relieve chafes, scratches, cuts and bites; transdermally, by dry powder syringe which itself does not penetrate the skin but which projects the drug material into the subcutaneous layers below; transdermally by "passive device" patches, e.g. nicotine worn by smokers trying to give up, which act as a local reservoir of an appropriate drug which permeates through the skin to the site of action unaided by additional fields or forces other than diffusion; transdermally, assisted electrically (i.e. iontophoretically) and/or in other ways.

Non-invasive routes minimise the chances of cross infection especially by the AIDS virus. 
Skin is one of the largest of the bodily organs, covering $2 \mathrm{~m}^{2}$, weighing $5 \mathrm{~kg}$ and being 2-3 mm thick. There are two key parts - the outer layer (epidermis) and the inner layer (dermis), between which there is a basement membrane. The most important layer within the epidermis is the stratum corneum, a 10-15 $\mu \mathrm{m}$ thick lipophilic barrier that minimizes transepidermal water loss, acts as a high-integrity barrier against egress of foreign material and has a high electrical resistance. The equivalent circuit is essentially the same as that for a polymer electrolyte as the stratum corneum has a high electrical resistance, in series with the dermis, which comprises a leaky capacitor (constant phase element) and a resistor in parallel. The stratum corneum is dry (20\% moisture compared with $70 \%$ for most of the rest of the body). Penetrating through the epidermis and providing a path from the outside world to deep within the dermis are hair follicles and pores which, in human skin, take up only about $0.1 \%$ of the surface area. The $\mathrm{pH}$ of the stratum corneum is $4-6$, being lowest just below the surface, whereas the hydrated tissue just under the basement membrane has a $\mathrm{pH}$ of about 7.3.

The history of iontophoresis has been described elsewhere $[6,7,12]$. Iontophoretic devices are in 3 parts - a power source providing up to $4 \mathrm{~mA}$ at constant current (corresponding to a $8 \mathrm{~cm}^{2}$ patch delivering the maximum desirable current density of 0.5 $\mathrm{mA} / \mathrm{cm}^{2}$ ) which, in the future, could well be a polymer electrolyte battery - a drug electrode which provides the reservoir of active ingredient - and an "indifferent" (or ground or dispersive) electrode $[43,44]$. The reservoir can be made from materials analogous to the polymer electrolytes originally developed by Michel Armand [45-47]. Sensor control of drug flux is very desirable and an impedance-based implantable microelectromechanical system (MEMS) device has recently been reported [48]. Drug penetration can be enhanced by chemical penetration enhancers such as PPG [49] or by sonophoresis using ultrasound[50]. 
There is a range of techniques related to iontophoresis $[6,11]$. Electroporation can be used to deliver DNA into cells and allow transdermal delivery of non-ionic drugs [51]. Reverse iontophoresis is used for non-invasive sampling of glucose and other blood constituents [52]. Iontophoresis can be used to treat hyperhidrosis or excess sweating, although "botox" has been found to be more successful [53]. A range of drugs can usefully be delivered by iontophoresis including lidocaine for local anaesthesia, cisplatin for basal cell carcinoma, vasopressin as an anti-diuretic and salmon calcitonin to control postmenopausal osteoporosis 6, 11]. Analogues of polymer electrolyte materials prepared for conventional solid state ionic devices have been shown to be suitable as iontophoretic reservoirs for lithium for the treatment of manic depression [54] and for lidocaine hydrochloride [55].

\section{References}

[1] R.J.Latham, R.G.Linford and W.S.Schlindwein, Solid State Ionics, 172 (2004) 7

[2] S.C. Barton, J. Galloway and P. Atanassov, Chem. Rev. 104 (2004) 4867

[3] E.Katz, O.Lioubashevski and I.Willner, J. Amer. Chem. Soc. 127 (2005) 3979

[4] A.Heller, Phys.Chem.Chem.Phys., 6 (2004) 209

[5] E.Katz, A.N.Shipway and I.Willner in: W.Vielstich, H.A.Gasteiger, A.Lamm (Eds.), Handbook of Fuel Cells - Fundamentals, Technology and Applications, John Wiley and Sons, London, 2003, vol.1, ch 21, p.355

[6] R.J.Latham, R.G.Linford and W.S.Schlindwein, Ionics, 9 (2003) 41

[7] R.J.Latham, R.G.Linford and W.S.Schlindwein in: B.V.R.Chowdari, S.R.S. Prabharan, M.Yahaya, I.A.Talib (Eds.), Solid State Ionics - Trends in the New Millenium, World Scientific, Singapore 2002, p.283 
[8] C.F.Holmes, Interface, 12 (2003) 19

[9] W.S.Gong and D.M.Merfeld, Ann.Biomed.Eng., 28 (2000) 572

[10] A. Helmstadter, Pharmazie, 56 (2001) 583

[11] Y.N.Kalia, A.Naik, J.Garrison and R.H.Guy, Adv.Drug Del. Rev., 56 (2004) 619

[12] F.O.V.da Cunha, M. M.C.Forte, A.Barnes, R.J.Latham, R.G.Linford and

W.S. Schlindwein in: K.Getlecker (Ed.), Functional Nanomaterials, American

Scientific Publishers, Stevenson Ranch, California, 2005 in press

[13] A-R Denet, R.Vanbever and V.Preat, Adv.Drug Del.Rev. 56 (2004) 659

[14] S Sershen, J West, Adv Drug Deliver Rev 54 (2002) 1225

[15] A.Heller, AICHE Journal 51 (2005) 1054

[16] J. Groen, C.Amiel , JLHR Bosch, Neurourology and Urodynamics 24 (2005) 226

[17] EH Kossoff, EK Ritzl, JM Politsky, AM Murro, JR Smith, RB Duckrow, DD Spencer, GK Bergey Epilepsia 45 (2004) 1560

[18] KB Baker, JA Nyenhuis, G,Hrdlicka AR Rezai, JA Tkach, FG Shellock J. Mag.Res.Imag. 21 (2005) 72

[19] M.H.Schoenfisch, M.Ovadia, J.E.Pemberton, J.Biomed. Mater. Res., 51 (1999) 209

[20] W. Greatbatch, W. Chardack, Proc. New England Res. \& Eng. Meeting 1 (1959) 8

[21] . G. Antonioli, F. Baggioni, F. Consiglio, G. Grassi, R. LeBrun, F. Zanardi, Minerva Med. 64 (1973) 2298

[22] A. Agarwal, M.York, B.K.Kantharia, M.Ezekowitz Ann. Rev. Med. 56 (2005) 475

[23] http://www.stcroixmedical.com/Envoy_device.htm (2005)

[24] PM Skarstad, J. Power Sources 136 (2004) 263 
[25] W. Greatbatch, V.C.F. Holmes, E.S. Takeuchi, S.J. Ebel, Pacing \& Clinical Electrophysiology 19 (1996) 1836

[26] C.L. Schmidt, P.M. Skarstad, J. Power Sources 97-98 (2001) 742

[27] E.S. Takeuchi, R.A. Leising, MRS Bull. 27 (2002). 624

[28] E Okamoto, T Inoue, K Watanabe, T Hashimoto, E Iwazawa, Y Abe, T Chinzei, T Isoyama, S Kobayashi, I Saito, F Sato, H Matsuki, K Imachi, Y Mitamura, Artificial Organs 27 (2003) 184

[29] H Klefenz, Eng in Life Sci, 4 (2004) 211

[30] S.C. Barton, Electrochim. Acta, 50 (2005) 2145

[31] M Yamada and I. Honma, Electrochim. Acta, 50 (2005) 2837

[32] G Tayhas, R Palmore and G M Whitesides, ACS Symp. Ser., 566 (1994) 271

[33] N L Akers and S.D.Minteer in: R K Shah, S G Kandlikar Eds., Fuel Cell Science, Engineering and Technology, Amer. Soc. Mechanical Engineers, New York, 2004, p.497 [34] www.cfsan.fda.gov/ rdb/opa-g106.html; www.cfsan.fda.gov/ rdb/opa-g122.html [35] R Bessant, A Steuer, S Rigby, M Gumpel, Rheumatology, 42 (2003) 1036

[36] X Ayral, Haemophilia, 7 (2001) 20

[37] I Schott, Chem. Eng. News, 81 (2003) 146

[38] S.Tsujimura, M.Fujita, H.Tasumi, K.Kano, T.Ikeda, Phys. Chem.Chem.Phys., 3 (2001) 1331

[39] S.Tsujimura, K.Kano, T.Ikeda, Electrochemistry, 70 (2002) 940

[40] E Katz, I Willner, A B Kotlyar, J. Electroanal. Chem., 479 (1999) 64

[41] N Mano, F Mao, A Heller, J. Amer.Chem.Soc., 124 (2002) 12962

[42] R Boulatov, Pure Appl. Chem., 76 (2004) 303

[43] A. Sharma. in 205th Meeting of The Electrochem. Soc., San Antonio, (2004), p.720. 
[44] J B Phipps in 205th Meeting of The Electrochem. Soc., San Antonio, (2004), p.714

[45] M. B. Armand, J. M. Chabagno and M. J. Duclot. in Second International Conference on Solid Electrolytes St. Andrews, Scotland, (1978).

[46] M. B. Armand, J. M. Chabagno and M. J. Duclot. in: P. Vashishta, J.N.Mundy, G.K.Shenoy (Eds.), Fast Ion Transport in Solids, Elsevier North-Holland Inc., 1979, 131

[47] C.Berthier, W.Gorecki, M.Minier, M.B.Armand and P.Rigaud, Solid State Ionics, 9 (1983) 1125

[48] A M Johnson, D R Sadoway, M J Cima, R Langer, J.Electrochem. Soc. 152 (2005) H6

[49] A K Banga, Electrically Assisted Transdermal and Topical Drug Delivery, Taylor and Francis, London, 1998

[50] S Mitragotri, J Kost, Adv. Drug Delivery Rev., 56 (2004) 589

[51] A-R Denet, R Vanbever, V Préat, Adv. Drug Delivery Rev., 56 (2004) 659

[52] B Leboulanger, R H Guy, M B Delgado-Charro, Physiol. Measurement 25 (2004) R35

[53] E Fitzgerald, T M Feeley, S Tierney, Surgeon-Journal Royal Coll. Surgeons Edinburgh \& Ireland, 2 (2004) 311

[54] T Sahota, R Latham, R Linford, P Taylor, Drug Dev. Ind. Pharm., 25 (1999) 307

[55] T Sahota, R Latham, R Linford, P Taylor, Drug Dev. Ind. Pharm., 26 (2000) 1039 


\section{Figure Captions}

Fig. 1: Schematic relationship between solid state ionics and medicine

Fig. 2: Time course of drug level following oral administration of conventional dosage forms compared to a long-acting, e.g. iontophoretic delivery system (MTC: minimum toxic concentration; MEC: minimum effective concentration).

Fig. 3: Schematic diagram of examples of: a) a microbial bioreactor supplying fuel inside the anodic compartment of an electrochemical cell; b) an enzymatic biofuel half cell showing the electron transfer through a redox mediator $\left(\mathrm{M} / \mathrm{M}^{+}\right)$. 


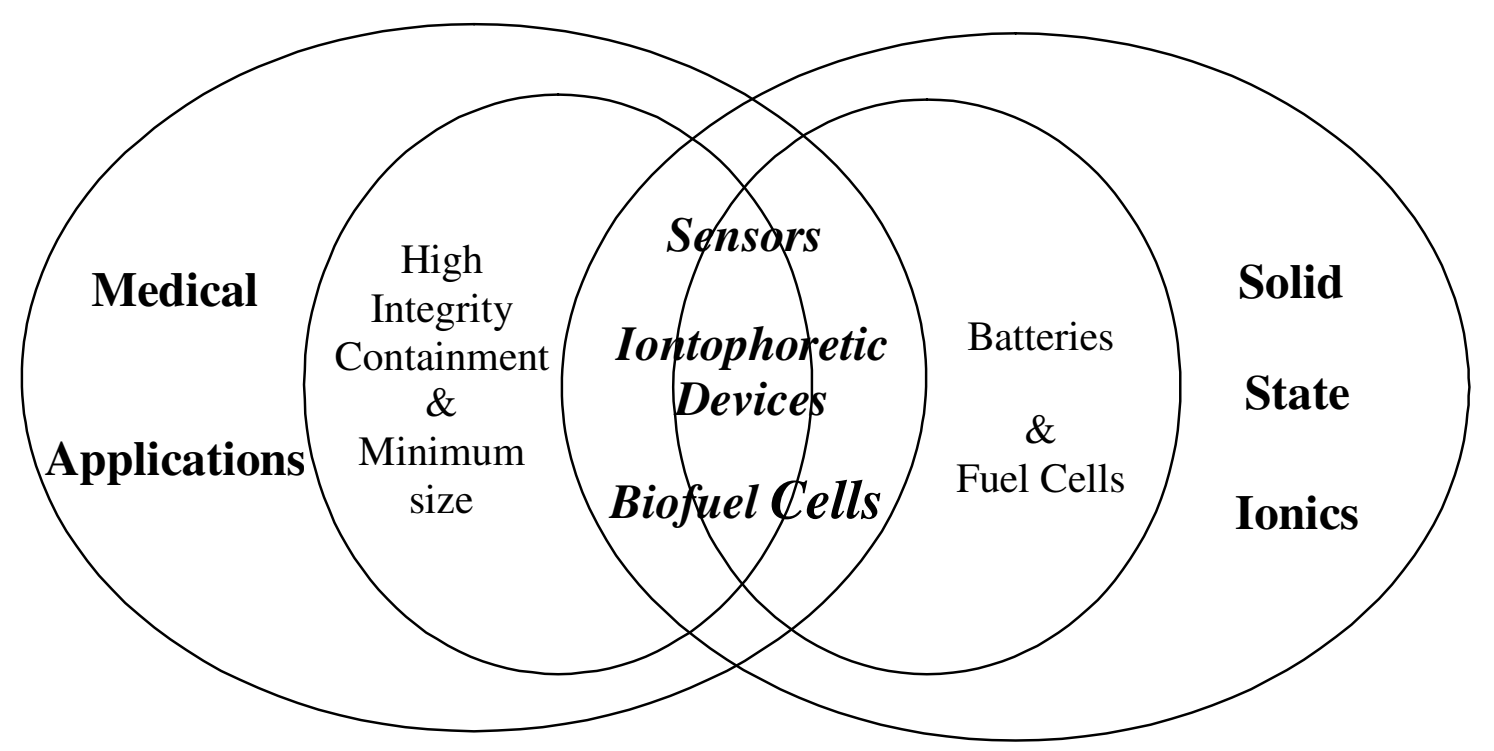

Fig. 1 


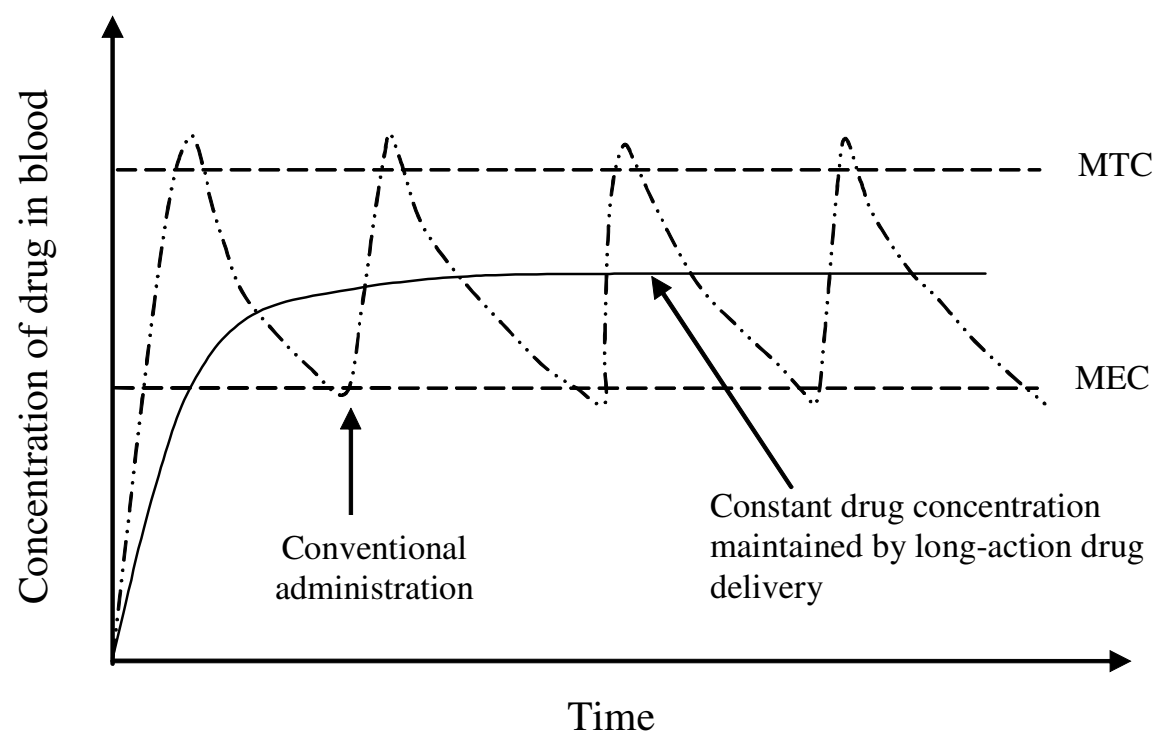

Fig. 2 


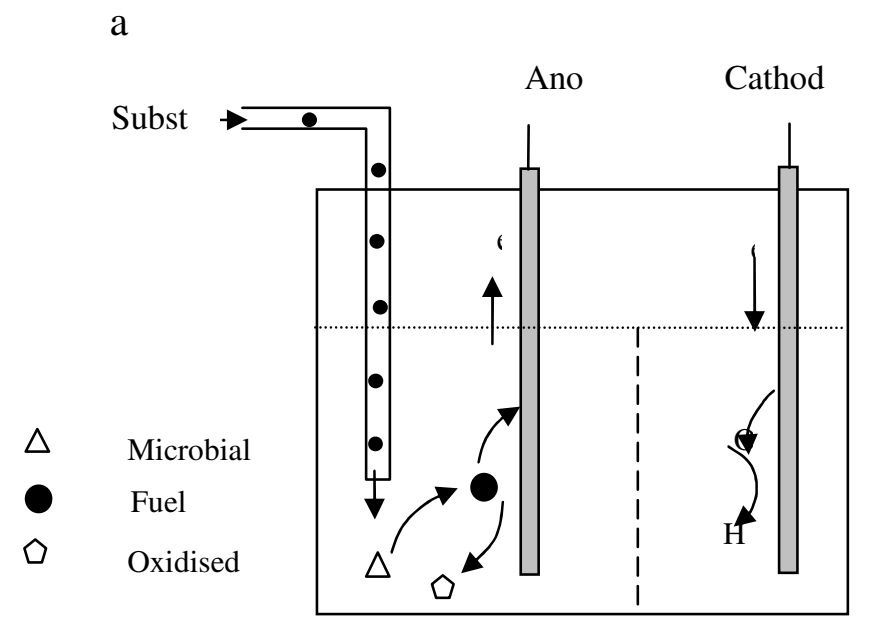

b

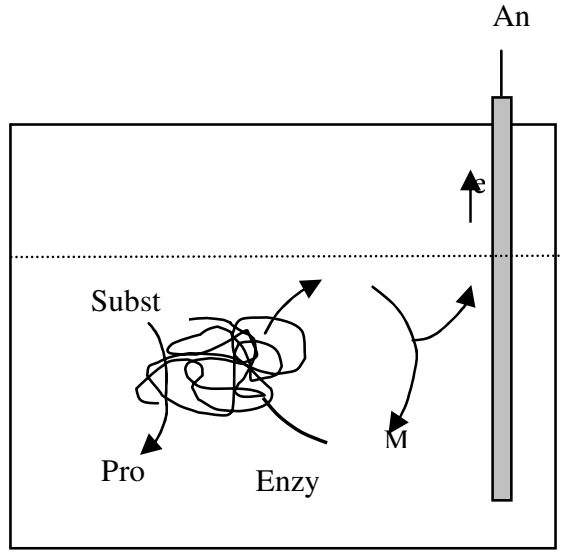

$$
\text { a }
$$

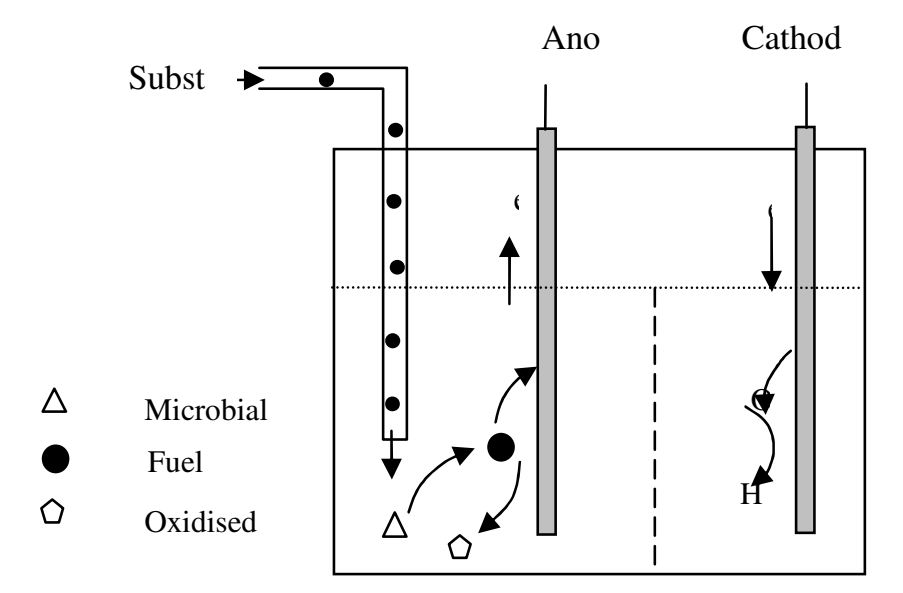

b

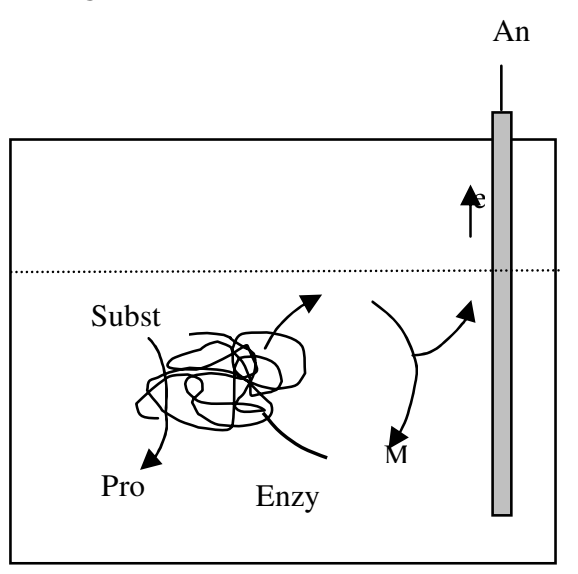

Fig.3 
